\title{
Checklist of fishes of the Bakhira Tal and their conservation status
}

\author{
FARAH BANO AND MOHAMMAD SERAJUDDIN \\ Fish Biology Research Lab, Department of Zoology, University of Lucknow, Lucknow - 226007 , Uttar Pradesh, India \\ e-mail:lu.fisheries@gmail.com
}

\begin{abstract}
The present study was carried out to assess the ichthyofaunal diversity of Bakhira Tal, a natural wetland in the district Sant Kabir Nagar of Uttar Pradesh. A total of 31 species belonging to 23 genera, 9 orders and 16 families were recorded. Maximum number of species recorded was from the Order Cypriniformes (32.25\%), which was followed by Perciformes (25.80\%), Siluriformes (16.12\%), Ophiocephaliformes (9.67\%), Beloniformes (3.22\%), Cyprinidontiformes (3.22\%), Symbranchiformes (3.22\%), Mastacembeleformes (3.22\%) and Tetraodontiformes (3.22\%). Most of the species recorded in the present study were under Least Concern (29) and two species namely Wallago attu and Ailia coila were found to be under Near Threatened Category of the International Union for Conservation of Nature (IUCN).
\end{abstract}

Keywords: Biodiversity, Ichthyofauna, IUCN, Threat, Wetland

Wetlands are inland fresh, brackish and marine water bodies which are transitional between terrestrial and aquatic ecosystems with water table at or near the surface of the land (Mitsch and Gosselink, 1986). Wetlands may be natural or artificial, permanent or temporary marsh, fern, peat land or water areas, static or flowing having depth not exceeding six meters at low tides (Scott, 1989). Moreover, they are often described as "kidneys of the landscape" (Mitsch and Gosselink, 1986) which cover an area of 58.2 million ha in India and are considered to be one of the most threatened habitats of the world (Prasad et al., 2002). Wetlands are productive ecosystems which play vital role in supporting the biodiversity, flood control (Mitsch and Gosselink, 1986; Zalidis and Gerakis, 1999), water purification and storage during dry seasons (Mwanuzi and Aalderink, 2003; Pauwels and Talbo, 2004). They are also known as "biological supermarkets" because of availability of extensive food chains and rich biodiversity that they support by providing unique habitats or home for a huge diversity of flora and fauna such as birds, mammals, fish, frogs, insects and plants (Buckton, 2007). Wetlands cover $0.80 \%$ of earth surface which contains $41 \%$ species of the world.

The Remote Sensing Application Centre, Lucknow reported that Uttar Pradesh has a total of 11,45,178 ha area (RSAC, 2009) of wetlands which is $4 \%$ of its geographical area. Bakhira Tal is a natural protected wetland located in Jaiswal Village, at a distance of $44 \mathrm{~km}$ from east of Gorakhpur City in Sant Kabir Nagar District of Eastern Uttar Pradesh. The wetland was declared as bird sanctuary in the year 1990 and considered as the largest natural flood plain of U.P., spread over an area of $29 \mathrm{~km}^{2}$. The landscape and terrain of the wetland is almost flat having an average height of $100 \mathrm{~m}$ representing a typical "Terai" landscape. The Bakhira Tal is a hotspot for large number of living organisms including fish, birds, aquatic plants and animals. Altogether 33,059 fish species have been recorded so far from all over the world (Eschmeyer and Fong, 2014). Biodiversity of aquatic ecosystems is under threat worldwide (Ricciardi and Rasmussen, 1999; Gibbs, 2000; Saunders et al., 2002; Dawson et al., 2003). Freshwater fishes are considered to be one of the most threatened taxonomic groups because of high sensitivity to the quantitative and qualitative alterations of aquatic habitats (Darwall and Vie, 2005; Dudgeon et al., 2006; Sarkar et al., 2008; Schmeller, 2008) due to human activity (Pullin, 2000; Schiemer, 2000; Abell, 2002; Oberdorff et al., 2002; Laffaille et al., 2005). The physiology, morphology and life history of species are directly affected by the environmental constraints (Williams et al., 2003; Skov and Svenning, 2004; Hilbert et al., 2004; Thomas et al., 2004). A survey of literature witnessed the paucity of information on the status of ichthyofaunal diversity of Bakhira Tal wetland. Therefore the current study was planned to give detailed information on the present status of piscean fauna and major threats affecting fish fauna of the Bakhira Tal.

Extensive field survey was carried out in order to collect the fish samples on monthly basis from Bakhira Tal (26 $54^{\prime} 390^{\prime \prime} \mathrm{N}$; 830' $\left.264^{\prime \prime} \mathrm{E}\right)$ using cast and drag nets for one year during January 2015 to December 2015. The sampled fishes were brought to the laboratory after preserving in 5\% formalin for further analyses. The map of the sampling site is given in Fig. 1. The fishes were identified using keys as given by Talwar and Jhingran (1991) and Jayaram (1999). 


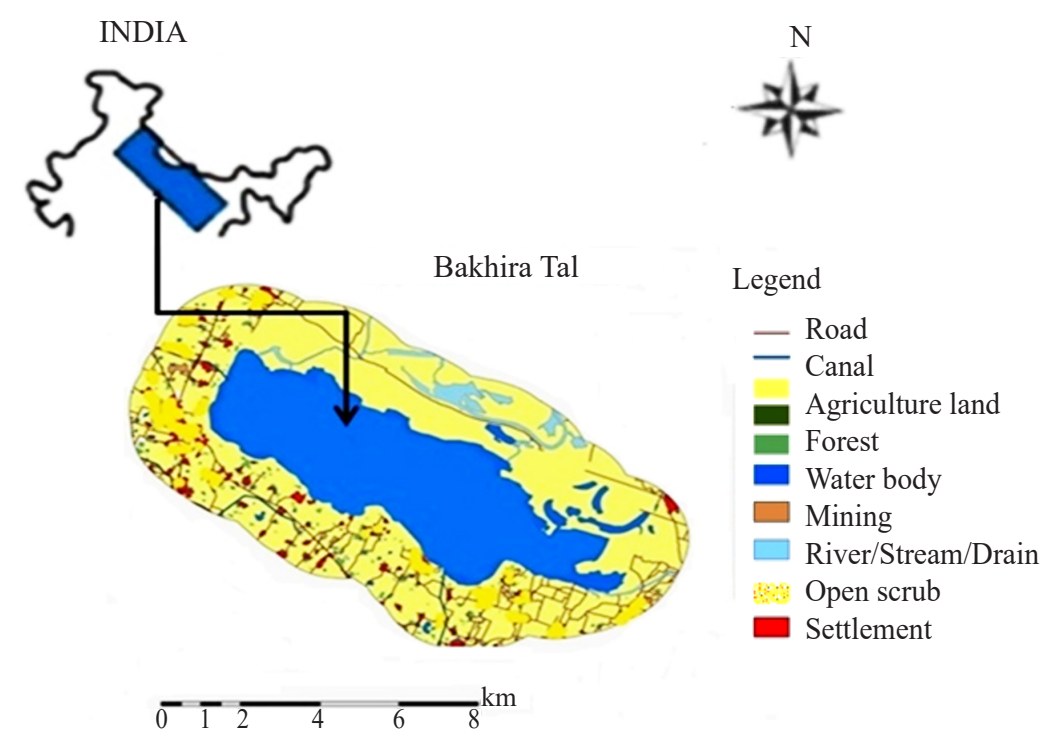

Fig. 1. Map of the sampling site

The threat status of each fish species was assessed according to the different categories as adopted and developed by International Union for Conservation of Nature and Natural Resources (IUCN, 2016).

A total of 31 species belonging to 23 genera, 9 orders and 16 families were recorded in the present study. The maximum number of species noted in the Bakhira Tal wetland were from the order Cypriniformes (32.25\%), which was followed by Perciformes (25.80\%), Siluriformes (16.12\%), Ophiocephaliformes (9.67\%) and others including Beloniformes, Cyprinidontiformes, Symbranchiformes, Mastacembeleformes and Tetraodontiformes that contributed $3.22 \%$ of the total species in isolation (Fig. 2). Among different families,

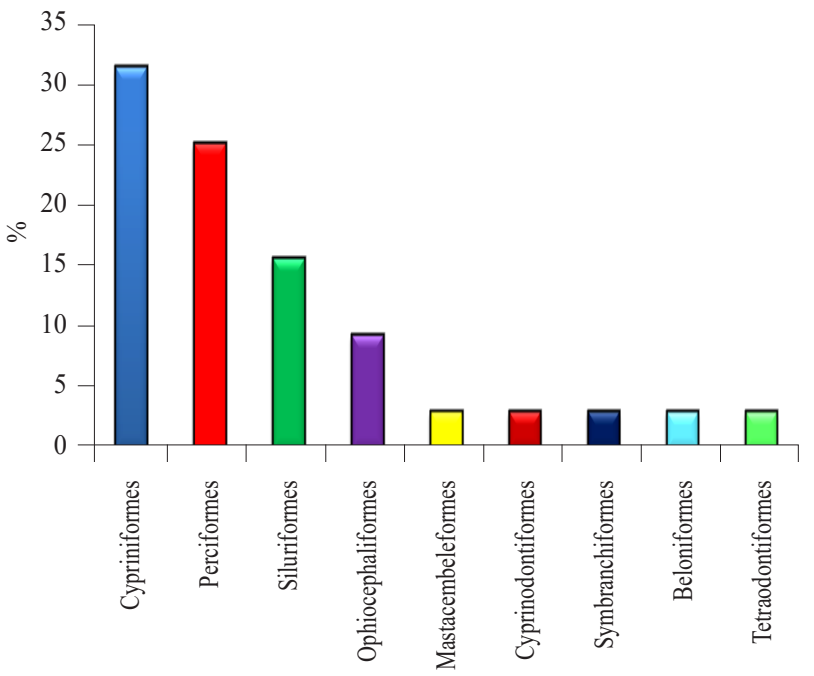

Fig. 2. Percentage representation of fishes at order level in the Bakhira Tal
Cyprinidae dominated in number of species by contributing $32.25 \%$ of total species, followed by Ophiocephalidae $(9.67 \%)$. Siluridae, Schilbeidae Osphronemidae and Ambassidae contributed $6.45 \%$ each and others contributed $3.22 \%$ individually of the total species recorded in the present study. The details are given in Fig. 3. Threat status of the fishes studied in Bakhira Tal indicated that most of the species (29) are under Least Concern (LC), and two species viz., Wallago attu and Ailia coila under Near Threatened category. The details of ichthyofauna, fin formula and IUCN status of fish recorded in Bakhira Tal wetland are given in Table 1, while recent trends of threats and conservation issues are shown in Fig. 4.

Cypriniformes was found to be the most dominant group as compared to other orders in the Bakhira Tal. The present finding is similar to that of the studies carried out by Shinde et al. (2009) and Jaiswal and Ahirrao (2012). Out of 15 families, Cyprinidae was most dominant with 10 species recorded during the current study. Devi Prasad et al. (2009) reported 45 species from wetlands of Mysore where Cyprinidae was dominant with 22 species. Sarwade and Khillare (2010) reported 60 species from Ujani wetland where Cyprinidae was dominant with 36 species. Das and Sabitry (2012) reported 62 ornamental fish species from the river island, Masuli, Assam where Cyprinidae was dominant with 20 species.

Most of the fishes of Bakhira Tal were found to be under Least Concern (LC) category and two species ( $W$. attu and A. coila) of order Siluriformes in Near Threatened (NT) category in the present study. Worldwide, recent estimates of biodiversity suggested that $20 \%$ of all freshwater species are extinct, endangered or vulnerable (Maclean and Jones, 1995). Wetlands are 
Table 1. Classification, local name, fin formulae and IUCN status of ichthyofauna of Bakhira Tal

\begin{tabular}{|c|c|c|c|c|c|}
\hline \multirow{2}{*}{$\begin{array}{l}\text { Order/Family } \\
\text { Cypriniformes/ } \\
\text { Cyprinidae }\end{array}$} & \multicolumn{2}{|c|}{ S. No. Species } & \multirow{2}{*}{$\begin{array}{l}\text { Local name } \\
\text { Dhawai }\end{array}$} & \multirow{2}{*}{$\begin{array}{l}\text { Fin formulae } \\
\text { D 2/7; P14; V9; A 2/5; C } 19\end{array}$} & \multirow{2}{*}{$\begin{array}{l}\text { IUCN status } \\
\text { LC }\end{array}$} \\
\hline & 1 & Amblyphyaryngodon mola & & & \\
\hline & 2 & Catla catla & Bhakur & D 18-19(3/15-16); P 19; V 9; A8(3/5); C 19 & $\mathrm{LC}$ \\
\hline & 3 & Cirrhinus mrigala & Nain & D16; P 18;V 9; A 2/6; C15 & $\mathrm{LC}$ \\
\hline & 4 & Cirrhinus reba & Rewa bata & D2/9; P16; V9; A2/6; C19 & $\mathrm{LC}$ \\
\hline & 5 & Labeo calbasu & Karaunchi & D 17(3/14); P19; V 9; A7(2/5); C 19 & $\mathrm{LC}$ \\
\hline & 6 & Labeo gonius & Kursi & D. $16(3 / 13) ;$ P. 17; V 9; A 7 (2/5); C19 & $\mathrm{LC}$ \\
\hline & 7 & Labeo rohita & Rohu & D 16(3/13); P 17; V 9; A7 (2/5); C 19 & $\mathrm{LC}$ \\
\hline & 8 & Labeo angra & Thuthunahia Raia & D 12-14; P 17; V 9; A 3/5; C 17 & $\mathrm{LC}$ \\
\hline & 9 & Oxygaster bacaila & Chalhawa & D 2/7-9; P12-13; V 9; A 2/13-15; C 19 & $\mathrm{LC}$ \\
\hline & 10 & Puntius sophore & Sidhari & D 3/ 8; P 15-16; V 9; A 3/5; C19 & $\mathrm{LC}$ \\
\hline \multirow{2}{*}{ Siluriformes/Siluridae } & 11 & Wallago attu & Padhani & D 5; P1/14; V 10; A 4/82; C17 & NT \\
\hline & 12 & Mystus vittatus & Tengara & D 1/ 7/0; P 1/8; V 6; A 2/9; C17 & $\mathrm{LC}$ \\
\hline \multirow[t]{2}{*}{ Schilbeidae } & 13 & Ailia coila & Patasi & D 0; P I 13-14; V 6; A 72-75; C 19 & NT \\
\hline & 14 & Pseudeutropius atherinoides & Barusa & D 1/6/10; P1/7; V 6; A 3/35; C 17 & $\mathrm{LC}$ \\
\hline Clariidae & 15 & Clarias batrachus & Mangur & D 65-70; P1/8; V6; A47; C17 & $\mathrm{LC}$ \\
\hline $\begin{array}{l}\text { Beloniformes/ } \\
\text { Belonidae }\end{array}$ & 16 & Xenentodon cancila & Kauwa & D 16-17; P 11; V 6; A 17; C 15 & $\mathrm{LC}$ \\
\hline $\begin{array}{l}\text { Cyprinodontiformes/ } \\
\text { Cyprinodontidae }\end{array}$ & 17 & Aplocheilus panchax & Dendula & D7; P 15; V 6; A 15; C 13 & $\mathrm{LC}$ \\
\hline \multirow{3}{*}{$\begin{array}{l}\text { Ophiocephaliformes/ } \\
\text { Ophiocephalidae }\end{array}$} & 18 & Channa marulius & Souri & D 46; P 18; V 6; A 32; C 12 & $\mathrm{LC}$ \\
\hline & 19 & Channa punctatus & Girohi & D 29-30; P 16-17; V 6; A 20-22; C 12 & $\mathrm{LC}$ \\
\hline & 20 & Channa striatus & Souri & D 41-43; P 16-18; V 6; A 24-25; C 14 & $\mathrm{LC}$ \\
\hline $\begin{array}{l}\text { Symbranchiformes/ } \\
\text { Amphipnoidae }\end{array}$ & 21 & Amphipnous cuchia & Baam & - & $\mathrm{LC}$ \\
\hline \multirow{2}{*}{$\begin{array}{l}\text { Perciformes/ } \\
\text { Ambassidae }\end{array}$} & 22 & Chanda baculis & Baam & D 1+7/1/13-14; P11-12; V 1/5; A3/5; C17 & $\mathrm{LC}$ \\
\hline & 23 & Chanda ranga & Chanari & D 1+7/1/16-17; P 12-13; V 1/ 5; A 3/16-18; C17 & $\mathrm{LC}$ \\
\hline Sciaenidae & 24 & Sciaena coitor & Bhola & D 11/2/27; P 17; V 1/5; A2/7; C 17 & $\mathrm{LC}$ \\
\hline Badidae & 25 & Badis badis & Sumha & D 16/ 7-10; P 12; V 15; A 3/7; C 16 & $\mathrm{LC}$ \\
\hline Nandidae & 26 & Nandus nandus & Dhebari & D 13/11-13;P 15; V 1/5; A3/8; C 15 & $\mathrm{LC}$ \\
\hline \multirow[t]{2}{*}{ Osphronemidae } & 27 & Trichogaster fasciata & Khosti & D 15-17/ 9-11; P 10; V1; A 16-17/ 15-16; C 15 & $\mathrm{LC}$ \\
\hline & 28 & Trichogaster lalia & Khosti & D 15-17 / 7-10; P 10; V 1; A 17-18/ 13-14 & $\mathrm{LC}$ \\
\hline Gobioidae & 29 & Glossogobius giuris & Bulla & D 6/1/9; P 20; V 1/ 5; A 1/8; C 17 & $\mathrm{LC}$ \\
\hline $\begin{array}{c}\text { Mastacembeleformes/ } \\
\text { Mastacembelidae }\end{array}$ & 30 & Macrognathus aculeatus & Bam & D 24-26 30-37; P 19; A 3/ 31-40; C 12 & $\mathrm{LC}$ \\
\hline $\begin{array}{l}\text { Tetraodontiformes/ } \\
\text { Tetraodontidae }\end{array}$ & 31 & Tetraodon cutcutia & Galphulani & D 10-11; P 18-21; A 10; C7 & $\mathrm{LC}$ \\
\hline
\end{tabular}

LC $=$ Least concern, $\mathrm{NT}=$ Near threatened

particularly important since $20 \%$ of the total threatened species in Asia are inhabitants of wetlands (Kumar et al., 2005). Prasad et al. (2002) reported that India is facing tremendous anthropogenic pressure, threatening and leading to extinction of fish species because of degradation of environment which alter the food web structure at the primary and secondary production levels of the ecosystem (Wrona et al., 2006). Vijayan et al. (2004) reported high concentrations of pesticides in fishes of the wetlands of Uttar Pradesh, which was higher than the maximum residue limits as suggested by Food and Drug Administration (Vijayan et al., 2004). Wetland environments are experiencing serious threat to both biodiversity and ecosystem stability. Working on conservation of biodiversity in freshwater ecosystems including wetlands, a number of workers such as Williams et al. (1989); Warren and Burr (1994); Cowx 


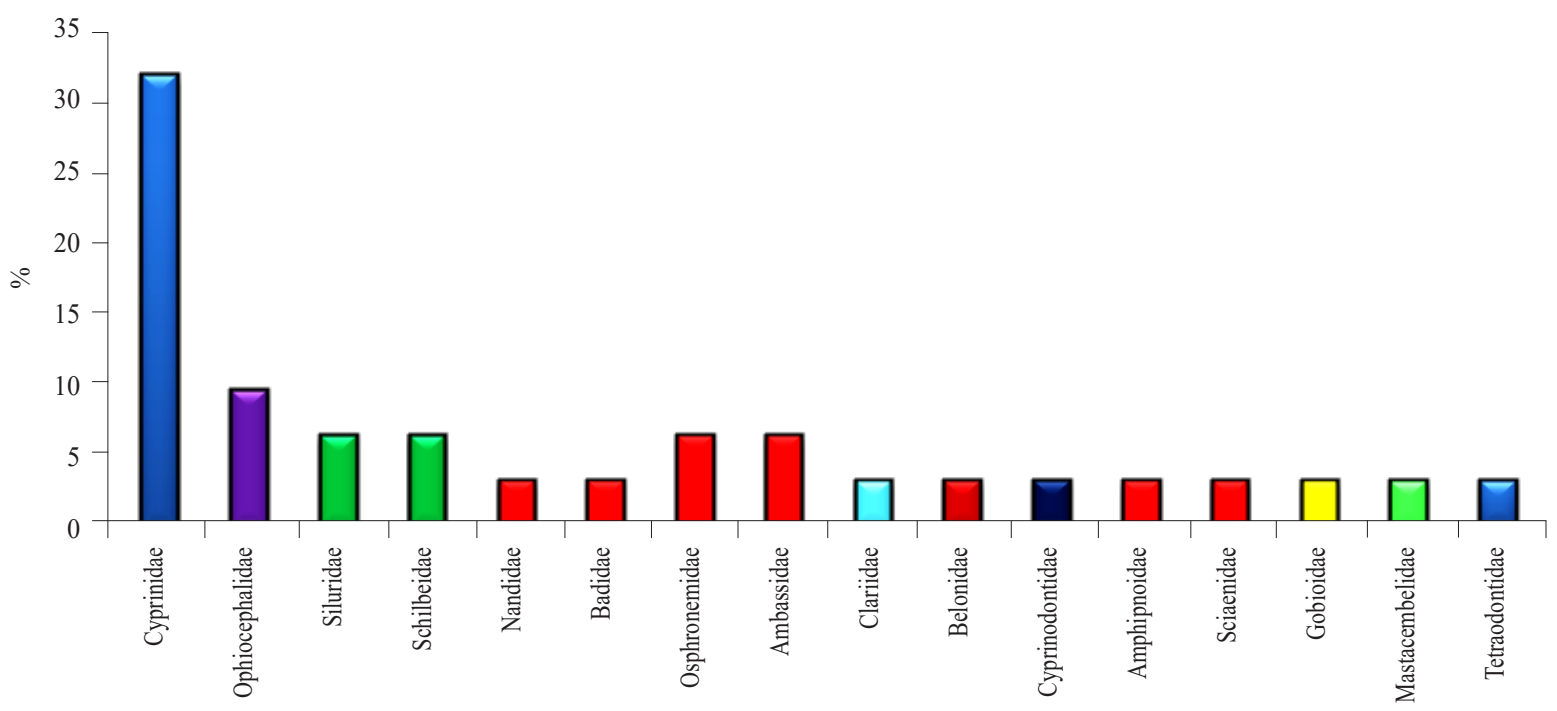

Fig. 3. Percentage representation of fishes at family level in the Bakhira Tal

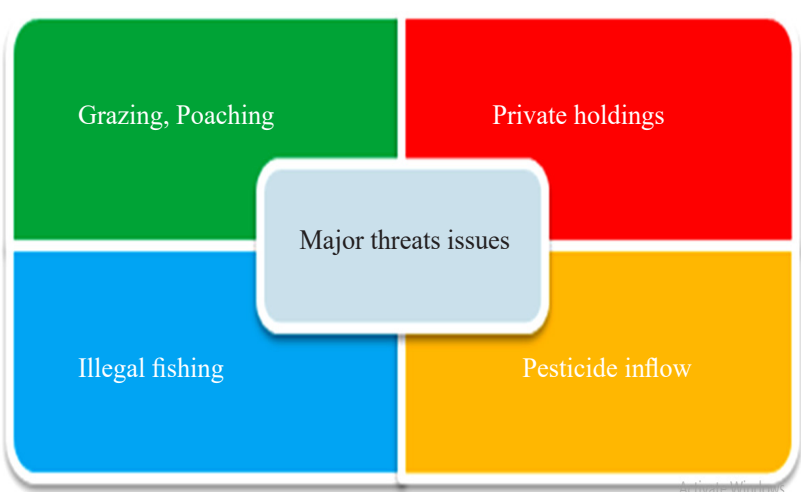

Fig. 4. Recent trend in threat issues of Bakhira Tal

(2002) as well as Suski and Cooke (2006) suggested many strategies such as mapping and modelling of wetlands for monitoring and preparation of inventory to solve the crisis. The wise use, surveys and intensive studies of different wetland ecosystems will bring out better results for the conservation of the wetlands. The preservation of wetland diversity is crucial not only for conservation of their rich biodiversity but also for meeting the basic needs of the local population.

\section{Acknowledgements}

The authors thank the Head, Department of Zoology, University of Lucknow for providing facility and administrative support. Authors are thankful to the University Grants Commission (UGC), New Delhi for the JRF fellowship [Ref No-19/06/2016(i) EU-V].

\section{References}

Abell, R. 2002. Conservation biology for the biodiversity crisis: a freshwater follow-up. Conserv. Biol., 16: 1435-1437.
Buckton, S. 2007. Managing wetlands for sustainable livelihoods at Koshi Tappu. Danphe, 16: 12-13.

Cowx, I. G. 2002. Analysis of threats to freshwater fish conservation: past and present challenges. In: CollaresPereira, M. J., Cowx, I. G., Coelho, M. M. (Eds.), Conservation of freshwater fishes: option for the future. Blackwell Scientific Press, UK, p. 201-220.

Darwall, W. R. T. and Vie J. C. 2005. Identifying important sites for conservation of freshwater biodiversity: extending the species-based approach. Fish. Manage Ecol., 12: 287-293.

Das, M. K. and Sabitry, B. 2012. Ichthyofaunal resources of inland water bodies of the river Island Majuli, Assam, India. Asian J. Exp. Biological Sci., 3: 51-58.

Dawson, T. P., Berry, P. M. and Kampa, E. 2003. Climate change impacts on freshwater wetland habitats. J. Nat. Conserv., 11: $25-30$.

Devi Prasad, A. G., Venkataramana, G. V. and Thomas, M. 2009. Fish diversity and its conservation in major wetlands of Mysore. J. Environ. Biol., 30: 713-718.

Dudgeon, D., Arthington, A. H., Gessner, M. O., Kawabata, Z. I., Knowler, D. J., Leveque, C., Naiman, R. J., Prieur-Richard, A. H., Soto, D., Stiassny, M. L. J. and Sullivan, C. A. 2006. Freshwater biodiversity: importance, threats, status and conservation challenges. Biol. Rev., 81: 163-182.

Eschmeyer, W. N. and Fong, J. D. 2014. Species by family/ subfamily. http://research.archive calacademy. org/research/ ichthyology/catalog/SpeciesByFamily.asp (Accessed 01 January 2017).

Gibbs, H. 2000. Wetland loss and biodiversity conservation. Conserv. Biol., 14: 314-317.

Hilbert, D. W., Bradford, M., Parker, T. and Westcott, D. A. 2004. Golden bowerbird (Prionodura newtonia) habitat in past, present and future climates: predicted extinction of 
vertebrate in tropical highlands due to global warming. Biol. Conserv., 116: 367-377.

IUCN 2016. International Union for Conservation of Nature and Natural Resources. www.iucnredlist. org (Accessed 01 January 2017).

Jaiswal, D. P. and Ahirrao, K. D. 2012. Ichthyodiversity of the Rangavali Dam, Navapur, District Nandurbar, Maharashtra State. J. Res. Biol., 3: 241-245.

Jayaram, K. C. 1999. The freshwater fishes of the Indian region. Narendra Publishing House, New Delhi, 551 pp.

Kumar, A., Sati, J. P., Tak, P. C. and Alfred, J. R. B. 2005. Handbook of Indian wetlands birds and their conservation Kolkata. Zoological Survey of India, 472 pp.

Laffaille, P., Acou, A., Guillouet, J. and Legault, A. 2005. Temporal changes in European eel, Anguilla anguilla, stocks in a small catchment after installation of fish passes. Fish Manage Ecol., 12: 123-129.

Maclean, R. H. and Jones, R. W. 1995. Aquatic biodiversity conservation: A review of current issues and efforts. Strategy for International Fisheries Research, 250 Albert Street, P. O. Box 8500, Ottawa, Canada K1G3H9.

Mitsch, W. I. and Gosselink, I. G. 1986. Wetlands, Van Nostrand Reinhold, New York.

Mwanuzi, F. and Aalderink, H. 2003. Simulation of pollution buffering capacity of wetlands fringing the Lake Victoria. Env. Int., 29: 95-103.

Oberdorff, T., Pont, D., Hugueny, B. and Porcher, J. P. 2002. Development and validation of a fish-based index (FBI) for the assessment of "river health" ' in France. Freshw Biol., 47: $1720-1734$.

Pauwels, H. and Talbo, H. 2004. Nitrate concentration in wetlands: Assessing the contribution of deeper groundwater from anions. Water Res., 38: 1019-1025.

Prasad, S. N., Ramachandra, T. V., Ahalya, N. T., Sengupta, T., Kumar, A., Tiwari, A. K., Vijayan, V. S. and Vijayan, L. 2002. Conservation of wetlands of India- A review. Trop. Ecol., 43: 173-186.

Pullin, R. S. 2000. Management of aquatic biodiversity and genetic resources. Rev. Fish. Sci., 8: 379-393.

RSAC 2009. Wetlands of Uttar Pradesh. Remote Sensing Application Centre (RSAC), Lucknow, Space Application Centre, Ahmedabad India, 108 pp.

Ricciardi, A. and Rasmussen, J. B. 1999. Extinction rate of North America freshwater fauna. Conserv. Biol., 13: 1220-1222.

Sarkar, U. K., Pathak, A. K. and Lakra, W. S. 2008 Conservation of freshwater fish resources of India: new approaches, assessment and challenges. Biodivers. Conserv., 17: 2495-2511.

Sarwade, J. P. and Khillare, Y. K. 2010. Fish diversity of Ujani wetland, Maharashtra, India. The Bioscan, 1: 173-179.
Saunders, D. L, Meeuwig, J. J. and Vincent, A. C. J. 2002. Freshwater protected areas: strategies conservation. Conserv. Biol., 16: 30-41.

Schiemer, F. 2000. Fish as indicators for the assessment of the ecological integrity of large rivers. Hydrobiologia, 422-423: $178-271$

Schmeller, D. S. 2008. European species and habitat monitoring: where are we now? Biodivers. Conserv., 17: 3321-3326.

Scott, D. A. 1989. A directory of Asian wetlands, IUCN, Gland, Switzerland and Cambridge, UK.

Shinde, S. E., Pathan, T. S., Raut, K. S., Bhandare, R. Y. and Sonawane, D. L. 2009. Fish biodiversity of Pravara River at Pravara Sangam District, Ahmednagar (M.S.), India. World J. Zool., 4: 176-179.

Skov, F. and Svenning, J. C. 2004 Potential impact of climatic change on the distribution of forest herbs in Europe. Ecography, 27: 366-380.

Suski, C. D. and Cooke, S. J. 2006. Conservation of aquatic resources through the use of freshwater protected areas: opportunities and challenges. Biodivers Conserv., 16: 2015-2029.

Talwar, P. K. and Jhingran, A. G. 1991. Inland fishes of India and adjacent countries. Oxford and IBH Publishing Co., New Delhi.

Thomas, C. D., Cameron, A., Green, R. E., Bakkenes, M., Beaumont, L. J., Collingham, Y. C., Erasmus, B. F. N., De Siqueira, M. F., Grainger, A., Hannah, L., Hughes, L., Huntley, B., Van Jaarsveld, A. S., Midgley, G. F., Miles, L., Ortega-Huerta, M. A., Peterson, A. T., Phillips, O. L. and Williams, S. E. 2004. Extinction risk from climate change. Nature, 427: 145-148

Vijayan, V. S., Prasad, S. N., Vijayan, L. and Muralidhararn, S. 2004. Inland wetlands of India conservation priorities. Salim Ali Centre for Ornithology and Natural History, Coimbatore, $532 \mathrm{pp}$.

Warren, M. L. and JrBurr, B. M. 1994. Status of freshwater fish of the United States: overview of an imperiled fauna. Fisheries, 19: 6-18.

Williams, J. E., Johnson, J. E., Hendricson, D. A., Contreeras-Balderas, S. Williums, J. D., Navarro-Mendoza, M., McAllister, D. E and Deacon, J. E. 1989. Fishes of North America endangered, threatened or of special concern. Fisheries, 14: 2-20.

Williams, S. E., Bolitho, E. E. and Fox, S. 2003. Climate change in Australian tropical rainforests: an impending environmental catastrophe. Proc. Biol. Sci., 270: 1887-1892.

Wrona, F. T., Prowse, J. D., Reist, J. D., Hobbie, J. E., Levesque, L. M. J. and Vincent, W. F. 2006. Climate change effects on aquatic biota, ecosystem structure and function. Ambio., 35: 359-369.

Zalidis, G. C. and Gerakis, A. 1999. Evaluating sustainability of watershed resources management through wetland functional analysis. Environ. Manage., 24: 193-207. 